\title{
State aid after the Banking Union: serious disturbance and public interest
}

\author{
Phedon Nicolaides ${ }^{1}$
}

Accepted: 21 June 2021 / Published online: 8 July 2021

(C) The Author(s), under exclusive licence to Springer Nature Limited 2021

\begin{abstract}
An objective of the European Union's Banking Union is to prevent Member States from having to subsidise banks. The Single Resolution Mechanism may have limited but has not eliminated state aid to banks. This is shown by the relevant statistics, the number of positive Commission decisions and the provisions of the Single Resolution Mechanism Regulation. State aid is allowed in three situations: when a bank is resolved, when it is liquidated and when it is solvent but needs temporary liquidity or more capital. This article identifies a difference between the European Commission and the Single Resolution Board in the interpretation of the concept of "public interest". The article further argues that this difference may not contradict the objectives of the Banking Union if state aid is still necessary to prevent damage to regional economies.
\end{abstract}

Keywords Single Resolution Board · Single Resolution Mechanism · State aid · Article 107(3)(b) TFEU · Serious disturbance $\cdot$ Public interest

\section{Introduction}

The purpose of this article is, first, to examine whether state aid to financial institutions may be granted now that the main components of the Banking Union are well in place and, second, if the granting of state aid is possible, under which conditions it can be done. While the academic literature during the past decade has examined in considerable detail the application of state aid rules to financial institutions, relatively little has been written on the interaction between European Union (EU) state aid rules and the resolution component of the Banking Union. ${ }^{1}$

Whether state aid to financial institutions is possible after the Banking Union is not an idle question. A fundamental objective of the Banking Union is to sever the link between sovereigns and banks [5, 6, 21]. A bank that gets into trouble has to be saved primarily by its shareholders or new investors. The burden on taxpayers has to be avoided or minimised. Indeed, recital 1 of Directive 2014/59 that established uniform rules for the recovery and resolution of credit institutions (BRRD) explains that "the objective of a

Phedon Nicolaides

phedon.nicolaides@maastrichtuniversity.nl

1 University of Maastricht, PO Box 616, 6200 MD Maastricht, The Netherlands credible recovery and resolution framework is to obviate the need for action (... and) to save institutions using taxpayers' money to the greatest extent possible" [23].

The default mode now is that troubled banks cannot be simply propped up with taxpayers' money in the form of state aid. They have to be liquidated or resolved. Liquidation means that the bank is wound up and its assets are sold to pay for its liabilities. In practice when this occurs, the assets are not sufficient to cover the liabilities so the shareholders and creditors of troubled banks normally lose some or most of their money. Resolution means that the bank is restructured in the public interest in order to preserve financial stability, secure the continuity of the bank's critical functions and minimise any costs to taxpayers [23, Article 31, 24 Article 14].

If taxpayers' money, or "extraordinary public financial support" (EPFS) as labelled in Article 2(28) of the BRRD, is used to support a troubled bank, it would constitute state aid. Although state aid has to be avoided, it is not altogether prohibited by the BRRD. As the Commission observed in its 2019 report on the application of the BRRD, "a bank must be declared failing or likely to fail when it needs

\footnotetext{
${ }^{1}$ For a review of the state aid rules that apply to the financial sector see, among others, Lienemeyer et al. [31], de Kok [3], Di Benedetto [4] and Laprévote et al. [30]. Specifically, on the interplay between state aid rules and resolution rules see Laprévote and Champsaur [29], Nicolaides [33, 34, 35] and Nicolaides and O'Connor [37]
} 
extraordinary public financial support to preserve its viability, liquidity or solvency, and only in specific exceptional cases a bank can receive public support without triggering that determination" [15, p 1]. These exceptional cases are defined in Article 32(4) of the BRRD. Moreover, recital 47 of the BRRD requires that "when the use of the resolution tools involves the granting of State aid, interventions should have to be assessed in accordance with the relevant State aid provisions".

The BRRD is addressed to all EU Member States and had to be transposed by 1 January 2015 . That meant that as of that date, any public measure to support banks would trigger their resolution or liquidation, unless the exceptions mentioned above would apply. Indeed, the Commission identified several banks that received EPFS in the form of temporary liquidity and capital injections without being resolved or liquidated (National Bank of Greece, Piraeus Bank and Monte dei Paschi di Siena) [15, p 4]. As we will see later on, those banks were deemed to be solvent and therefore they could benefit from the exception in Article 32(4) of the BRRD.

The EU's Banking Union divides the tasks of bank supervision and bank resolution between two different bodies. Supervision is carried out by the Supervisory Board of the European Central Bank [2]. ${ }^{2}$ Resolution is the responsibility of the Single Resolution Board (SRB) which was set up as a separate EU agency. Given that a bank can be resolved only when it is deemed to fail, there is close "horizontal" cooperation between the $\mathrm{ECB} / \mathrm{SB}$, in charge of assessing whether a bank is failing or likely to fail (FoLF), and the SRB. The decision-making organs of both bodies include Member State representatives. Therefore, the need for cooperation is also "vertical", i.e. between the national and the European levels. Since this article focuses on state aid, as we will see later on, effective cooperation between the SRB and the Commission, on the one hand, and between national authorities and the Commission, on the other, are also important.

The SRB, which became operational on 1 January 2015, has been vested with powers to resolve banks in the euro area plus Bulgaria and Croatia that joined the Banking Union as of 1 October 2020. The substantive provisions of Regulation 806/2014 that established the Single Resolution Mechanism and the SRB (SRMR) came into force only on 1 January 2016 [24].

The SRMR, like the BRRD, does not prohibit state aid. Recital 30 of the SRMR stipulates that "where resolution

\footnotetext{
2 The Supervisory Board of the Single Supervisory Mechanism was established by Council Regulation (EU) No 1024/2013 of 15 October 2013 conferring specific tasks on the European Central Bank concerning policies relating to the prudential supervision of credit institutions, OJ L 287, 29 October 2013.
}

action would involve the granting of State aid pursuant to Article 107(1) TFEU or as Fund aid, a resolution decision can be adopted after the Commission has adopted a positive or conditional decision concerning the compatibility of the use of such aid with the internal market".

The SRMR also established the Single Resolution Fund (SRF) which is capitalised with contributions by banks. The SRB is empowered, if it deems it necessary, to provide resources from the SRF to support the resolution of a bank (e.g. to preserve its critical functions). Because it may be thought that resources deployed at EU level by the SRB do not constitute state aid (given that they are not granted by national authorities), the SRMR, like the BRRD, lumps together national money and money at EU level into the concept of "extraordinary public financial support". Article 3(1)(29) of the SRMR indeed defines "extraordinary public financial support" to mean "State aid within the meaning of Article 107(1) TFEU or any other public financial support at supra-national level, which, if provided at national level, would constitute State aid, that is provided in order to preserve or restore the viability, liquidity or solvency" of a financial institution [The same definition appears in Article 2(1)(28) of the BRRD].

The important point is that when a bank receives EPFS, regardless of whether it is granted by a Member State or the SRB, it is considered to be failing or likely to fail and, in principle, it must be liquidated or resolved [Article 18(4) SRMR \& Article 32(4) BRRD], unless the exception applies. This exception is explained in detail in Sect. 3.

Therefore, compliance with state aid rules is not only required of decisions of national resolution authorities. It is also binding on the SRB. This leads to the second question that is tackled in this article and is, probably, of greater interest from a constitutional perspective. How do the decisions of the SRB - an EU agency-coexist, for want of a better word, or correlate with those of the European Commission which enjoys exclusive competence in the EU to determine the compatibility of state aid with the internal market.

It is worth noting that compliance with state aid rules is required of the ECB as well. Recital 32 of Regulation 1024/2013 [10] that established the Single Supervisory Mechanism (SSM) provides that "the ECB should carry out its tasks subject to and in compliance with relevant Union law including the whole of primary and secondary Union law, Commission decisions in the area of State aid, competition rules and merger control and the single rulebook applying to all Member States" [2].

The structure of this article is as follows. Section 2 sets the context and demonstrates that indeed state aid in the financial sector is not a thing of the past. It reviews the relevant statistics and decisions of the Commission. Section 3 explains under which conditions state aid may be used to support banks. Section 4 considers what happens when a 
Table 1 State aid to banks: amount approved/amount used [billion euro] in EU2

\begin{tabular}{lllll}
\hline & $\begin{array}{l}\text { Annual average } \\
2008-10\end{array}$ & 2016 & 2017 & 2018 \\
\hline Recapitalisation & 330 & $8.5 / 0.1$ & $25.7 / 11.3$ & $9.2 / 0.2$ \\
Guarantees & 1135 & $310.7 / 118.4$ & $328.5 / 107.4$ & $153.3 / 87.5$ \\
$\begin{array}{l}\text { Comparator: Total state aid EU28 } \\
\text { [industry and services] }\end{array}$ & 55 & 106 & 116 & 121 \\
\hline
\end{tabular}

European Commission, DG Competition, State Aid Scoreboard, 2019 failing bank is not resolved by the SRB. Section 5 examines whether the decisions of the SRB reveal a different assessment to that of the Commission on the need to grant state aid to banks and argues that it is reasonable that the SRB and the Commission interpret the same concept differently. However, these differences create legal uncertainty that needs to be remedied. Section 6 concludes and summarises the main points of the article.

The main findings of the article are, first, that state aid to banks has been significantly reduced but not eliminated. Second, the SRMR (and the BRRD) allow state aid only for solvent banks that have systemic significance. By contrast, under state aid rules, aid may also be granted to less significant banks and liquidated banks. Third, despite this apparent difference between the SRMR and state aid rules, state aid for liquidation purposes does not necessarily contradict the objectives of the SRMR (or the BRRD). However, clarification of the criteria used by the SRB and the Commission would increase legal certainty. By contrast, state aid to solvent but non-systemic banks may trigger conflicting assessments by the Commission and national authorities. In this case there is a more urgent need for explicit guidance from the Commission.

\section{The context: state aid to banks in the period 2016-2019}

Although the amount of state aid granted to banks has certainly declined from the heights it reached in 2008-10, it is still not insignificant. The latest edition of DG Competition's annual Scoreboard on state aid was published in the Spring of 2020 and includes data up to 2018 . Table 1 presents available statistics for the years 2016 to 2018 for the whole of the EU.

The two main categories of state aid for banks were injections of fresh capital to strengthen banks' ability to withstand adverse developments [recapitalisation] and state guarantees to enable banks to issue new debt instruments such as bonds. To put things in perspective, Table 1 also shows the total amount of state aid granted to banks in 2008-2010 and aid granted to industry and services in the EU-28 in 2016-2018. The numbers in the Table indicate that despite the formation of the Banking Union and the application of uniform rules on resolution, Member States still grant large amounts of aid to the financial sector, although it must be said that they grant much less than ten years ago and less than what the Commission formally authorises. In other words, Member States notify to the Commission the maximum amounts they expect to grant, but do not necessarily utilise those maximum amounts.

In terms of the number of measures assessed by the Commission, the "case search tool" of DG Competition reveals that from 1 January 2016, when the SRMR came into force, to 31 December 2019, just before the declaration of the COVID-19 pandemic, there were 56 state aid measures concerning banks which were decided on the basis of Article 107(3)(b) TFEU. This Article allows state aid for the purpose of remedying a serious disturbance in the economy of Member States. Table 2 groups the 56 cases in six categories.

Most cases concern prolongations and amendments of existing aid measures rather than new measures with fresh amounts of aid. Existing aid is aid that is already approved by the Commission. Given that in Table 2 only two cases concern guarantees, it follows that most of the aid in the form of guarantees shown in Table 1 is granted in the context of existing measures.

What is also indicated by Table 2 is that aid can be granted in the context of sale of assets or of whole banks and to support the restructuring and liquidity of banks, without

Table 2 Commission decisions on financial institutions: 1/1/2016$31 / 12 / 2019$

Type of cases

Prolongations \& amendments of existing schemes 32

Liquidation, winding up, resolution $\quad 10$

Sale of assets/banks $\quad 5$

Liquidity support 4

Restructuring 3

Guarantees 2

Total $\quad 56$

European Commission, DG Competition, case search tool; classification by the author 
the aid recipients being resolved. As we will see in the next section this is possible because there is an exception to the rule that troubled banks must either be liquidated (i.e. wound u) or resolved.

\section{COVID-19 and the 2020 temporary framework}

In mid-March 2020, the Commission adopted a Temporary Framework concerning state aid measures implemented by Member States to combat the effects of COVID-19 [16]. ${ }^{3}$ The main purpose of those measures was to provide liquidity to companies which suffered a sudden drop in their revenue as a result of the lockdown. A considerable proportion of those measures were in the form of state guarantees for loans and subsidies for interest on loans. In the period 15 March to 1 October 2020, the Commission approved 288 measures of which 82 were guarantees for loans and 56 were interest subsidies. ${ }^{4}$ Since loans are provided by banks, these state aid measures stimulate demand for loans and therefore banks can obtain an indirect advantage [36].

However, section 3.4 of the Temporary Framework explains that such indirect aid, if any, does not trigger the resolution provisions of the BRRD or the SRMR. As clarified in the Temporary Framework, “(29) While such aid is directly targeting undertakings facing a sudden liquidity shortage and not credit institutions or other financial institutions, it may also constitute an indirect advantage to the latter. Nevertheless, such indirect aid does not have the objective to preserve or restore.

the viability, liquidity or solvency of the credit institutions. As a result, the Commission considers that such aid should not be qualified as extraordinary public financial support according to Article 2(1) No 28 BRRD and Article 3(1) No 29 SRMR, and should not be assessed under the State aid rules applicable to the banking sector" [16, pp 1-9].

Therefore, indirect aid is still possible for banks. For example, the direct recipients of public subsidies to indebted households are not considered to receive state aid because they do not constitute undertakings in the meaning of Article 107(1) TFEU. However, such measures may involve indirect aid to banks which enjoy the benefit of avoiding foreclosure of housing loans at a loss. This kind of indirect aid to banks has been approved by the Commission on the basis of

\footnotetext{
${ }^{3}$ The Temporary Framework was amended four times between March and October 2020. A consolidated version can be accessed at: https://ec.europa.eu/competition/state_aid/what_is_new/TF_conso lidated_version_amended_3_april_8_may_29_june_and_13_oct_ 2020_en.pdf

4 Author's calculations based on the Commission's data bank on state aid cases which can be accessed at:

https://ec.europa.eu/competition/elojade/isef/index.cfm?fuseaction= dsp_sa_by_date
}

Article 107(3)(c), which is the typical legal basis for authorisation of most types of state aid, rather than Article 107(3) (b) which allows aid only for the purpose of remedying a serious economic disturbance and, very rarely, for important projects of common European interest. For the indirect aid to banks, the Commission did not invoke either the banking guidelines or the provisions of the BRRD/SRMR [7, 14].

\section{Resolution v liquidation: SRMR rules}

Article 18(1) of the SRMR requires the SRB to "adopt a resolution scheme" when the following conditions are met:

(a) the entity is failing or is likely to fail.

(b) there is no reasonable prospect that any alternative private sector measures would prevent its failure.

(c) a resolution action is necessary in the public interest pursuant to paragraph 5 of Article 18.

According to Article 18(4), a bank is FoLF in one or more of the following circumstances:

(a) withdrawal of the authorisation by the ECB [e.g. losses that deplete its own funds].

(b) the assets of the entity will be less than its liabilities.

(c) the entity is unable to pay its debts or other liabilities.

(d) extraordinary public financial support is required.

And, according to Article 18(5), a resolution action is in the public interest if it is necessary for the achievement of, and is proportionate to one or more of the resolution objectives in Article 14 and winding up of the bank under normal insolvency proceedings would not meet those resolution objectives to the same extent.

Article 14(2) defines the following resolution objectives:

(a) to ensure the continuity of critical functions.

(b) to avoid significant adverse effects on financial stability.

(c) to protect public funds by minimising reliance on EPFS.

(d) to protect "covered" depositors. ${ }^{5}$

(e) to protect client funds and client assets.

Pursuant to these provisions, a troubled bank must normally be liquidated. However, it can be resolved rather than liquidated if it is in the public interest in order to achieve the objectives laid down in Article 14(2). The SRB published

\footnotetext{
5 Under EU law, deposits up to EUR 100,000 are guaranteed or "covered" by Member States.
} 
in 2019 more detailed criteria for assessing public interest in a document entitled "Public Interest Assessment: SRB Approach" [40]. Accordingly, resolution is in the public interest when the troubled bank provides critical functions to the economy and its failure can have a negative impact on other financial institutions and disrupt normal financial transactions. In other words, resolution is in the public interest when the bank is systemically significant.

The above conditions can be summarised as follows. If a bank is FoLF, and its shareholders or other private investors are not able or willing to save the bank because its prospects are dim, and the bank is significant in the sense that its closure under normal insolvency proceedings would harm financial stability in the countries where the bank operates, then the SRB may resolve the bank.

Before the BRRD and the SRMR came into force, state aid was the kiss of life for banks. But now, as stipulated by Article 18(4) SRMR [or Article 32(4) BRRD], state aid or EPFS has become the kiss of death. The granting of state aid to a bank automatically categorises the recipient as FoLF, and a FoLF bank must be resolved or liquidated.

However, there is an exception laid down in Article 18(4) (d) of the SRM Regulation [and Article 32(4)(d) BRRD] whenever the EPFS is granted to an otherwise solvent bank for the purpose of remedying a serious disturbance in the economy of a Member State and to preserve financial stability. In this case the EPFS is limited to:

(i) State guarantees to back liquidity facilities provided by central banks.

(ii) State guarantees of newly issued liabilities.

(iii) Injection of own funds or purchase of capital instruments.

Moreover, such measures must be of "a precautionary and temporary nature" and proportionate to remedy the consequences of the serious disturbance. Injections of capital must address capital shortfalls established by stress tests which, for systemic banks in the euro area, are carried out by the ECB in its supervisory capacity.

Article 19(1) of the SRMR requires that "where resolution action involves the granting of State aid pursuant to Article 107(1) TFEU or of Fund aid ..., the adoption of the resolution scheme under Article 18(6) of this Regulation shall not take place until such time as the Commission has adopted a positive or conditional decision concerning the compatibility of the use of such aid with the internal market". It is clear that the powers of the Commission to assess state aid extend also to the resources of the Single Resolution Fund (SRF).

At this point, it should be clarified that a bank may be FoLF for reasons other than receiving EPFS [e.g. it may have incurred excessive losses, or its liabilities exceed its assets] and the SRB may resolve the bank without the use of state aid. Indeed this happened in the case of Banco Popular Español. It was resolved in 2017 and its good assets and deposits were sold to Banco Santander for EUR 1 without the Spanish government injecting in it any public money or the SRB mobilising resources from the SRF [44]. ${ }^{6}$

Therefore, the question that arises is whether there are situations in which the SRB and the Commission may reach a different assessment with respect to the need of a bank to receive state aid or EPFS. Answers to this question are provided below.

\section{Three possibilities for divergent assessments between the Commission and the SRB}

In theory there are three possible situations in which the SRB's and the Commission's assessments of a bank's need for state aid or EPFS to diverge.

\section{Diverging assessments in the classification of public capital as state aid}

The first possibility which is rather theoretical is when the SRB considers an injection of public capital not to constitute state aid, while the Commission reaches the opposite conclusion. For example, the SRB may agree with the claim of a Member State that it acts as a private investor seeking to make profit and that the financial transaction in which it is involved is free of state aid. In this case, no resolution procedure will be initiated. There appear to be no cases of this kind involving the SRB to date, although there are several recent cases in 2019-2020 where Member States acted as private investors injecting capital that was found by the Commission to be free of state aid [13, 17, 19].

\section{No resolution aid but liquidation aid}

A second scenario in which the SRB and the Commission may reach a different conclusion could occur where the SRB may decide that a bank that is FoLF does not fulfil one or more of the conditions for which resolution is warranted. For example, it may consider the bank not to be significant and, therefore, resolution not to be necessary for preserving financial stability. A bank that is FoLF, but which is not resolved by the SRB, must be liquidated. Member States are not precluded from granting state aid to facilitate liquidation and the Commission may authorise such state aid. Indeed,

\footnotetext{
${ }^{6}$ The decision was updated in March 2020 after the final valuation of the assets of the bank was completed. It can be accessed at: https://srb.europa.eu/en/content/banco-popular.
} 
this happened in at least two cases involving Italian banks: Banca Popolare di Vincenza (BPVI) and Veneto Banca (VB) $[10,11]$.

The SRB decided not to resolve them because resolution was not in the public interest [Article 18(1)(c)]. With respect to Veneto Banca, the SRB found that "the failure of the Institution, on a standalone basis, is not likely to result in significant adverse effects on financial stability in Italy". And "considering the relatively low financial and operational interconnections with other financial institutions, an adverse impact (contagion) on other financial institutions and considerable spill-over effects to other intermediaries are regarded highly unlikely". The SRB concluded that "while a potential adverse impact on retail customers and SMEs in certain regions, in which the Institution has a stronger presence, cannot be excluded, there would be no significant impact at national level" [41, section 4.2.2]. The SRB reached the same conclusions with respect to Banca Popolare di Vincenza [42, section 4.2.2].

Yet, the Commission in decision SA.45664 authorised liquidation aid for the two banks on the grounds that "(95) Article 107(3)(b) TFEU enables the Commission to find aid compatible with the internal market if it is 'to remedy a serious disturbance in the economy of a Member State." "(98) According to the Italian authorities it would not be possible to avoid a serious disturbance in the economy in the areas where VB and BPVI operate with a particular impact on interruption of SME's business activities and lending to households". "(99) In view of the above the Commission considers that Measures ... for the liquidation and sale of assets and liabilities of VB and BPVi have to be assessed under Article 107(3)(b) TFEU" [9].

While the SRB thought that a potential adverse regional impact could not be excluded, the Commission believed that it would not be possible to avoid serious regional disturbance.

The European Court of Auditors (ECA), in a special report on state aid to banks published on 1 October 2020, criticised the Commission for lack of clarity in its treatment of state aid in those cases [22]. The ECA observed that "(66) the Commission considered that Member States were best placed to make an initial assessment whether an uncontrolled market exit of a particular bank would threaten financial stability (or cause other serious disturbance in the Member State). Correspondingly, the Commission did not contest whether a serious disturbance existed in each individual case".

"(68) For cases of liquidation aid, the Commission did not contest Member States' assertions that a potential bank failure constituted a threat to financial stability. ... All decisions concerned banks with market shares ranging from $0.02 \%$ to $2 \%$. There are a number of potential reasons why the failure of even a non-systematically relevant bank could pose a potential threat to financial stability. For the cases we examined, we consider that the Commission did not explain these reasons in the published decisions".

Even though the ECA's special report criticised the Commission for not explaining those reasons, it itself failed to indicate what they may be. Naturally, one may construct valid explanations of how the failure or even rumours of impending failure of a non-systemic bank may impact negatively on financial stability. But the ECA and, especially, the Commission have a responsibility to pursue clear policies. After all, the purpose of the Commission's state aid guidelines is to "guide" Member States to design measures that are compatible with the internal market.

It is not necessarily an undesirable outcome that two different EU institutions make different assessments and reach different conclusions. The SRB is required to take into account the broader public interest as defined in the SRMR. The Commission may consider other aspects of the public interest or the public interest at regional level as defined by Article 107(3)(b) TFEU. However, as argued in Sect. 5, these different understandings or definitions of public interest should be spelled out and made more explicit.

\section{Aid to solvent banks, but no resolution}

The third situation where difference of views between the SRB and the Commission may arise is in the application of the exception in Article 18(4)(d) of the SRMR. The granting of EPFS does not automatically make the recipient FoLF when it is solvent and the measure, among other things, is intended to be temporary [for liquidity or to increase capital in the adverse scenario], to remedy a serious disturbance in the economy of a Member State and to preserve financial stability.

Like in the previous situation, the SRB may find that an otherwise solvent bank that requires more capital, for example, in the adverse scenario, is not systemically significant and, therefore, EPFS would not be necessary to preserve financial stability. Consequently, the EPFS would trigger its categorisation as FoLF. Since, however, financial stability would not be threatened, the SRB would not initiate its resolution. If the Commission would authorise state aid for such a bank, we would have, again, a difference between the SRB and the Commission in the assessment of the need for aid to support public interest.

Although no such cases have occurred, for at least three banks (Attika Banca, Lithuanian Credit Union and Banca Carige), the Commission authorised state aid despite the fact that an adverse impact on financial stability was very unlikely. Had these cases been assessed by the SRB, it is rather probable that the SRB would have reached a different conclusion. The Commission decisions in the following cases did consider the position of these banks in their 
respective financial system. When bearing in mind that the Article 6 of the SSM Regulation defines a systemic bank as having assets exceeding EUR 30 billion or $20 \%$ of the corresponding country's GDP, it is obvious that banks with market shares of a couple of percentage points are not systemic [8 Assets EUR 3.7 billion, estimated market share slightly over 1\%, 12 Assets EUR 290 million, estimated market share about 1\%, 18 Assets EUR 24 billion, estimated market share about $1 \%$.

\section{What happens if a bank is not resolved by the SRB?}

SRB decisions are addressed to national authorities. If a bank is not resolved, it is up to the competent national authority to decide what to do next. For example, in the case of Banca Popolare di Vincenza and Veneto Banca, the SRB warned that if any public funds were used to restructure the banks or facilitate the transfer of their assets to another bank, they would constitute state aid requiring prior approval by the Commission. The same language was used in the SRB's decision on ABLV bank [43, Recital 134].

There is no case law on the application of the concept of public interest to resolution of banks. ${ }^{7}$ But it is clear that when the SRB does not take action, the responsibility for the failing bank falls on the shoulders of national authorities.

Since its creation, the SRB has been involved, always as defendant, in 22 court cases before the Court of Justice or the General Court of the EU for which judgement has already been rendered. ${ }^{8}$ The SRB is still involved in about 160 pending cases. Two of the closed cases reached the

\footnotetext{
7 Although it may appear surprising there is also no definition of public interest in the case law on state aid, apart from the requirement that a state aid measure must promote an objective for which state aid is allowed by the Treaty in Articles 93, 106(2), 107(2) and 107(3). This is because it falls within the discretion of Member States to define the objectives of their state aid measures, provided, of course, that they remain within the provisions of the relevant Treaty Article. In the landmark case, T-356/15, Austria v Commission, EU:T:2018:439, the General Court, first, reiterated that "(48) in order to be capable of being declared compatible with the internal market pursuant to Article 107(3)(c) TFEU, aid must be aimed at the development of an activity that constitutes a public interest objective and must be appropriate, necessary and not disproportionate". It then went on to make two important clarifications: "(86) ... the interest had to be a public interest and not just a private interest of the beneficiary of the aid measure" [i.e. it must support an objective of public policy] and "(87) ... it cannot be inferred from this that the public interest objectives that may be pursued by a Member State are limited to those that are common to all or to the majority of the Member States" [i.e. the specific policy objective need not be shared by all Member States].

${ }^{8}$ Calculations by the author on the basis of results generated by the search engine of the Court of Justice.
}

Court of Justice and concerned the calculation of banks' contributions to the SRF and procedural issues. The 20 cases that were heard before the General Court concerned mostly the calculation of contributions and demands for compensation of damage caused by the resolution Banco Popular Español and the non-resolution of ABLV bank of Latvia [1, $26,28,39]$.

So far the SRB has decided to resolve only one bank [Banco Popular Español (2017)] and not to resolve four banks [Banca Popolare di Vincenza (2017), Veneto Banca (2017), ABLV bank (2018), and PNB Banka of Latvia (2019)].

In the case of $A B L V$, investors initiated proceedings against the SRB. The General Court in case T-282/18, Bernis and others $\mathrm{v}$ SRB, dismissed the action brought by those investors. According to Article 263(4) of the Treaty on the Functioning of the EU (TFEU) any natural or legal person may appeal against an act addressed to that person or which is of "direct and individual concern" to them. For investors, this is a problem because resolution decisions are not addressed to shareholders. In the case of the ABLV Bank, the decision of the SRB was addressed to the competent authority in Latvia. Therefore, the General Court had to consider whether Bernis and the other investors could claim that they were "directly and individually concerned" as required by Article 263 TFEU. In the end, the General Court rejected the claim of "direct and individual concern" on the grounds that the decision of the SRB did not affect the legal rights of the applicants as shareholders of the bank and that the decision for liquidation was the responsibility of national authorities.

In arriving at that conclusion, the General Court, first, observed that "(37) indeed, winding up does not flow from the contested decisions without the application of other intermediate rules of national law". In other words, when the SRB decides not to resolve a bank, the fate of the bank is in the hands of the national authorities.

The General Court went on to confirm that "(43) the contested decisions give the national authorities discretion as regards the adoption of measures likely to affect the rights of the shareholders of ABLV Bank and ABLV Luxembourg. Although it is true that the winding up of those two credit institutions is such as to affect the applicants' rights, those windings up do not, however, constitute an implementation of the contested decisions which is 'purely automatic and resulting from the EU rules alone', .... Thus, the relevant EU rules, in this case Regulation No 806/2014, make no provision, ..., for the winding up of a credit institution in respect of which the SRB has decided not to adopt a resolution scheme on the ground that the conditions set out in the first subparagraph of Article 18(1) of that regulation are not satisfied". 
For the purposes of this article the relevant issue is the finding of the General Court that the decision to wind up the bank could not be imputed to the SRB. This judgement also implicitly highlights that, had the national authorities decided to grant state aid, it would not have been contrary to the SRMR because it is silent on what happens to a bank that is not resolved by a decision of the SRB.

As was explained earlier, in the case of the Italian banks Banca Popolare di Vincenza and Veneto Banca, the Commission, in decision SA.45664, approved state aid to facilitate their liquidation. Hence, state aid to a bank that is not resolved does not infringe the SRMR. However, national authorities must comply with the requirements of Article 32(4) of the BRRD which is identical to Article 18(4) of the SRMR. The determination of whether it is in the public interest to grant state aid to resolve, liquidate or provide temporary support to a bank is unavoidable.

\section{Concept of public interest}

As shown above in the case of the two Italian banks that were not resolved by the SRB, there were distinct linguistic differences in the decisions of the SRB and of the Commission. But apart from these linguistic differences, one may argue that in fact, the SRB and the Commission applied different concepts of "public interest". The SRB obviously considered the national interest, while the Commission took into account the regional interest. Legally, this difference is significant because EU courts established some time ago that the reference to a "serious disturbance in the economy of a Member State" in Article 107(3)(b) TFEU means the entire economy, not just a part of it [25].

In its judgement in case C-57/00 P, Freistaat Sachsen v European Commission, EU:C:2003:510, the Court of Justice endorsed the findings of the General Court in case T-132/96 [25]. The Court of Justice confirmed that "(97) unlike points (a) and (c) of Article [107](3) of the Treaty, point (b) of that paragraph requires a serious disturbance in the economy of a Member State, not of regions, since a disturbance in the economy of the latter would not necessarily affect that of the Member State concerned".

In fact, the Court of Justice went further and stressed that the Commission enjoys wide discretion in determining the existence of a serious disturbance and that it is only subject to a check by EU courts whether it has committed a "manifest error" in this respect.

According to the Court of Justice, "(99) the question of the extent of the serious disturbance in the economy ... involves complex assessments of an economic and social nature which fall within the wide discretion enjoyed by the Commission, and that no concrete evidence had been put before it capable of establishing that that institution made a manifest error of assessment in that respect". "(100) No criticism can be made of that finding by the [General Court], so that the German Government is wrong to submit that the mere reference to the provision, in the context of a known factual situation, suffices to show that the conditions for the application of Article [107](3)(b) of the Treaty were satisfied".

Given the discretion it enjoys, perhaps the Commission considers that even though the disturbance must be economy-wide, the alleviation of its impact can be regional. Indeed the words in Article 107(3)(b) TFEU "to remedy a serious disturbance" can be understood in two different ways. First, it is clear from the case law that the disturbance must affect the whole economy. But, second, this does not necessarily prevent the intervention that mitigates the harm from an economy-wide disturbance to be local or regional. The Commission has never formally made this distinction, but it has alluded to this interpretation in several decisions. For example, in a case concerning liquidity support to the Italian Banca Carige, the Commission explained, in case SA.52917, that the aid was compatible with the internal market on the basis of Article 107(3)(b) because "(41) given the substantial weight of the Bank in the Ligurian economy, the Commission finds that the measures aim at ensuring financial stability and thus at remedying a serious disturbance in the economy, especially at the regional level".

However, it must be said that the main rules applicable to the financial sector-i.e. the 2013 Banking Communication-indicate the opposite [6]. In this Communication the Commission keeps emphasising the need to preserve financial stability in the sector and the economy as a whole.

"(6) In those circumstances of persisting stress in financial markets and given the risk of wider negative spill-over effects, the Commission considers that the requirements for the application of Article 107(3)(b) of the Treaty to State aid in the financial sector continue to be fulfilled. The application of that derogation remains, however, possible only as long as the crisis situation persists, creating genuinely exceptional circumstances where financial stability at large is at risk". The last sentence, in particular, implies that the intervention should aim to preserve financial stability "at large'; i.e. in the whole system or whole economy.

"(7) Financial stability implies the need to prevent major negative spill-over effects for the rest of the banking system which could flow from the failure of a credit institution as well as the need to ensure that the banking system as a whole continues to provide adequate lending to the real economy. Financial stability remains of central importance in the Commission's assessment of State aid to the financial sector under this Communication".

"(25) Credit institutions exhibit a high degree of interconnectedness in that the disorderly failure of one credit institution can have a strong negative effect on the financial system 
as a whole. Credit institutions are susceptible to sudden collapses of confidence that can have serious consequences for their liquidity and solvency. The distress of a single complex institution may lead to systemic stress in the financial sector, which in turn can also have a strong negative impact on the economy as a whole, for example through the role of credit institutions in lending to the real economy, and might thus endanger financial stability".

Specifically with respect to liquidation aid, the Banking Communication states: "(66) The Commission recognises that, due to the specificities of credit institutions and in the absence of mechanisms allowing for the resolution of credit institutions without threatening financial stability, it might not be feasible to liquidate a credit institution under ordinary insolvency proceedings".

Although the 2013 Banking Communication refers extensively to financial stability, it makes no mention of "public interest" or whether state intervention may aim to prevent regional instability. For example it does not indicate who has to determine that a bank that requests state aid or EPFS is solvent so as to avoid resolution or liquidation. The 2019 report of the Commission on the BRRD and SRMR explains that a recapitalisation "measure is conditional on final approval under the Union State aid framework. The Commission has observed that there may be a need for further clarification of the conditions and the procedure to grant precautionary recapitalisation, ... For example, the framework does not specify which authority should confirm that the bank is "solvent" before it receives precautionary recapitalisation" [15, 24, p 5].

Silvia Merler, of the Brussels think tank Bruegel, attributes the difference in the interpretation of "public interest" between the Commission and the SRB to another gap in the Banking Communication: the absence of a detailed definition of "critical functions". "While the definition of critical functions seems to be clear insofar as it concerns the SRB's assessment of the existence of public interest, it is not equally clear what role it plays in the EU discipline on liquidation aid, which is mostly contained in the Commission's 2013 Communication". She concludes that "in the absence of clarity on what constitutes a serious impact on the regional economy, the rules on liquidation aid leave room for governments to effectively re-instate at the local level the public interest that the SRB has denied at national (or, in the Italian case, even at the regional) level" [32, p 11]. In a speech in May 2019, the chair of the SRB, Elke König, did acknowledge the "lingering asymmetries between the EU resolution regime and the national insolvency frameworks" [27].

The cases of Attica Bank, Banca Carige and the Lithuanian Credit Union lend support to the view that the Commission interprets the concept of remedying a serious disturbance more widely than the SRB. It appears to consider state aid under Article 107(3)(b) not only as a means of mitigating damage to the whole economy but also for repairing regional damage caused by a nation-wide disturbance or for preventing further damage, especially additional damage that may be caused by the liquidation of regional banks.

Unfortunately, there are no judgements on Article 107(3) (b) that provide guidance as to whether aid to remedy a serious disturbance may also be granted to financial institutions with limited size or geographic spread.

Nonetheless, if we understand the objective of remedying a serious disturbance in the economy in Article 107(3)(b) to mean that the source of the problem must be economy-wide without limiting any aid to economy-wide undertakings or economy-wide measures, then aid to a small, regional bank that has been affected by such an economy-wide problem is not necessarily incompatible with the internal market in the meaning of EU case law.

Nor would it be incompatible with secondary legislation. As already explained, state aid to a non-systemic bank that is not resolved by the SRB would not necessarily be contrary to the SRMR as long as such a bank is liquidated. Liquidation aid is neither allowed, nor prohibited by the SRMR. It is for the Commission to assess whether it would be in the public interest to permit such aid so as to prevent further damage to regional or national economies.

However, it is difficult to justify the case of state aid to solvent but non-systemic banks. Since they are not systemic, EPFS would not be necessary to preserve financial stability. But national authorities, rather than the SRB, would have to consider them FoLF on the basis of Article 32(4) of the BRRD. Article 32(4) is identical to Article 18(4) of the SRMR. It states that "an institution shall be deemed to be failing or likely to fail in one or more of the following circumstances: ... extraordinary public financial support is required except when, in order to remedy a serious disturbance in the economy of a Member State and preserve financial stability" [emphasis added]. EPFS to a solvent bank can be granted only if it satisfies two conditions: remedy a serious disturbance and preserve financial stability. The latter condition seems to exclude non-systemic banks. It is for the Member States and the Commission to justify how EPFS to small, regional banks can threaten the financial stability of the whole economy. So far, the Commission seems to have acknowledged that state aid may preserve regional stability. The ECA special report 21/2020 has suggested that regional instability may spread and cause national instability. This may be correct. However, no such reasoning has been articulated yet in any Commission decision. Systemic significance means that there are horizontal channels of financial contagion from one bank to another and from the financial system to the real economy. We need an explanation of when state aid can remedy instability that is spread through vertical 
channels of financial contagion [from regional to national levels].

In its reply to the ECA observations, the Commission claimed that it leaves the assessment to national authorities. "The Commission notes that it is the Member State concerned that has to demonstrate that aid was necessary because of a threat to financial stability in the absence of State aid. ... Against the above background, the Commission confirms that it took into account the Member State's submissions in the assessment of the serious disturbance in each individual case" [20, p 68].

This is not a satisfactory state of affairs for at least two reasons. First, it creates legal uncertainty for Member States as to what the Commission may accept and does not ensure equal treatment of all Member States, if they do not notify to the Commission measures designed according to the same criteria.

Second, it implicitly creates two standards of assessment: one for the countries in the Banking Union and another for the rest of Member States. In the Banking Union it is conceivably more difficult for national authorities to argue that a bank is significant when the SRB concludes that it is not or that its failure may cause damage beyond regional level when the SRB finds that unlikely. By contrast, banks in nonparticipating countries are not subject to assessment by a supra-national agency. The national resolution authority may view differently the significance even of a small bank. Future research should test empirically how the absence of participation of the SRB in the case of Member States outside the Banking Union has affected public funding for the resolution, liquidation or liquidity support of banks.

It is appropriate to end this section by emphasising the obligation for uniform application of EU law, especially where the law does not explicitly stipulate that Member States can exercise discretion. As cogently expressed recently by the Court of Justice, "it follows from the requirements both of the uniform application of EU law and the principle of equality that the wording of a provision of EU law that does not contain any express reference to the law of the Member States in order to determine its meaning and scope must, throughout the European Union, be interpreted independently and uniformly, irrespective of characterisation in the Member States, taking into account the wording of the provision at issue and also its context and the purpose of the rules of which it forms part" [38, para 44].

\section{Conclusions}

An objective of the EU's Banking Union is to prevent Member States from subsidising banks with taxpayers' money. The SRMR and the BRRD may have limited but have not eliminated state aid to banks. This is shown by the relevant statistics, the number of positive Commission decisions and the provisions of the SRMR and the BRRD.

State aid is possible when a bank is resolved, when it is liquidated but also when it is solvent and needs temporary liquidity or needs to increase its capital.

The SRMR does not prohibit Member States participating in the Banking Union from granting state aid, although state aid in the form of EPFS may trigger the resolution of the recipient bank. As long as aid is intended to remedy a serious disturbance in a Member State's economy, the Treaty allows it on the basis of Article 107(3)(b).

The SRB is also empowered by the SRMR to grant financial support ["Fund aid"] using the SRF but does not have any competence to prohibit state aid.

Therefore, ultimately, whether state aid may be granted to banks depends on the Commission and how strict it wishes to make the relevant rules which they are currently laid down in the 2013 Banking Communication.

Between October 2008, when its first Communication on state aid to banks was published, and July 2013, when the current Communication was adopted, the Commission progressively tightened the rules and attached many restrictions to authorised state aid measures. At the same time, however, this article explains that the Commission seems to have interpreted Article 107(3)(b) in a way that accommodates state aid to banks which are liquidated and to less significant banks. This widens the circle of potential state aid recipients.

Moreover, as a result of the covid-19 pandemic, indirect aid to banks is not considered to fall within the definition of "extraordinary public financial support" that triggers resolution provisions.

State aid to facilitate liquidation and to provide temporary support to less significant banks may be in the public interest. This article argues that the Commission has to formally confirm that this kind of aid is compatible with the internal market and define explicitly the criteria for assessing it so that there is clarity for Member States and banks themselves.

Acknowledgements I am indebted for valuable comments on an earlier draft to Marcel Magnus and Tony O'Connor, to the participants of the Workshop on Constitutional Challengers in the Field of Financial Regulation that was held on 19 October 2020, in collaboration between the University of Maastricht, the University of York and Sciences Po. I am also particularly grateful to the editors of this special issue for their questions and suggestions.

\section{Declarations}

Conflict of interest The author states that there is no conflict of interest. 


\section{References}

1. Banco Cooperativo Español v Single Resolution Board. 2019. ECLI:EU:T:2019:822.

2. Council Regulation (EU) No 1024/2013 of 15 October 2013 conferring specific tasks on the European Central Bank concerning policies relating to the prudential supervision of credit institutions. OJ L 287, 29 October 2013.

3. de Kok, J. 2015. Competition policy in the framework and application of state aid in the banking sector. European State Aid Law Quarterly 14 (2): 224-240.

4. Di Benedetto, F. 2017. State aid and the banking system in the financial crisis: From bail-out to bail-in. Journal of European Competition Law and Practice 8 (2): 88-98.

5. European Commission. 2012. New crisis management measures to avoid future bank bail-outs. Press Release, 6 June, https://ec. europa.eu/commission/presscorner/detail/en/IP_12_570.

6. European Commission. 2013. Communication on state aid rules to support measures for banks (Banking Communication). OJ C 216, 30 July 2013.

7. European Commission. 2016. Decision no. SA.45004 against Cyprus on State grant scheme to borrowers and micro-companies. OJ C 302, 19 August 2016.

8. European Commission. 2017. Decision no. SA.46558 against Greece on Liquidity Support to Attica Bank. OJ C 51, 17 February 2017.

9. European Commission. 2018. Decision no. SA.45664 against Italy on Orderly Liquidation of Banca Popolare di Vicenza and Veneto Banca. OJ C 236, 6 July 2018.

10. European Commission. 2018. Decision no. SA.47149 against Italy on Liquidity Support to Banca Popolare di Vicenza. OJ C 140, 20 April 2018.

11. European Commission. 2018. Decision no. SA.47150 against Italy on Liquidity Support to Veneto Banca. OJ C 140, 20 April 2018.

12. European Commission. 2018. Decision no. SA.48920 against Lithuania on Recapitalisation of the Lithuanian Central Credit Union. OJ C 40, 2 February 2018.

13. European Commission. 2019. Decision no. SA.53519 against Greece on Hellenic Asset Protection Scheme ('Hercules'). OJ C 388, 15 November 2019.

14. European Commission. 2019. Decision no. SA.53520 against Greece on Primary Residence Protection Scheme. OJ C 396, 22 November 2019.

15. European Commission. 2019. Report from the Commission to the European Parliament and the Council on the application and review of Directive 2014/59/EU (Bank Recovery and Resolution Directive) and Regulation 806/2014 (Single Resolution Mechanism Regulation). COM (2019) 213 final, 30 April 2019, https:// ec.europa.eu/transparency/regdoc/rep/1/2019/EN/COM-2019213-F1-EN-MAIN-PART-1.PDF.

16. European Commission. 2020. Communication on Temporary Framework for State aid measures to support the economy in the current COVID-19 outbreak. OJ C 911, 20 March 2020.

17. European Commission. 2020. Decision no. SA.49094 against Germany on market-conform measures for strengthening capital and restructuring of Norddeutsche Landesbank. OJ C 25, 24 January 2020.

18. European Commission. 2020. Decision no. SA.52917 against Italy on Liquidity Support to Banca Carige, Cassa di Risparmio di Genova e Imperia. OJ C 7, 10 January 2020.

19. European Commission. 2020. Decision no. SA.53869 against Romania on market-conform recapitalisation of CEC Bank. OJ C 74, 6 March 2020.

20. European Commission. 2020. Final Replies to the European Court of Auditors' Special Report no. 21.
21. European Council. 2012. Conclusions point 11. 13-14 December, https://www.consilium.europa.eu/uedocs/cms_data/docs/press data/en/ec/134353.pdf.

22. European Court of Auditors. 2020. Control of State aid to financial institutions in the EU: In need of a fitness check. Special Report no. 21.

23. European Parliament and Council Directive 2014/59/EU of 15 May 2014 establishing a framework for the recovery and resolution of credit institutions and investment firms. OJ L 173, 12 June 2014.

24. European Parliament and Council Regulation 806/2014/EU of 15 July 2014 establishing uniform rules and a uniform procedure for the resolution of credit institutions and certain investment firms in the framework of a Single Resolution Mechanism and a Single Resolution Fund. OJ L 225, 30 July 2014.

25. Freistaat Sachsen and Others v Commission. 1999. ECLI:EU:T:1999:326.

26. Hypo Vorarlberg Bank v Single Resolution Board. 2019. ECLI:EU:T:2019:823.

27. König, E. 2019. Resolution and liquidation: Closing the gaps. Article presented at the Single Resolution Board; 7 May 2019, Brussels, Belgium.

28. Landesbank Baden-Württemberg v Single Resolution Board. 2020. ECLI:EU:T:2020:435.

29. Laprévote, F.-C., and A. Champsaur. 2017. Hand in hand or parallel paths? Reflections on the future coexistence of State aid control and bank resolution in the EU. In (2017) Research handbook on state aid in the banking sector, ed. F.-C. Laprévote, J. Gray, and F. de Cecco, 54-84. Cheltenham: Edward Elgar.

30. Laprévote, F.-C., J. Gray, and F. de Cecco, eds. 2017. Research handbook on state aid in the banking sector. Cheltenham: Edward Elgar.

31. Lienemeyer, M., C. Kerle, and H. Malikova. 2014. The new state aid banking communication: The beginning of the bail-in era will ensure a level playing field of enhanced burden-sharing. European State Aid Law Quarterly 13 (2): 277-288.

32. Merler, S. 2017. Bank Liquidation in the European Union: Clarification Needed. Bruegel; Policy Contribution, issue 32.

33. Nicolaides, P. 2017. Extraordinary public financial support for banks is not so extraordinary after all. Maastricht Journal of European and Comparative Law 24 (3): 343-347.

34. Nicolaides, P. 2017. State aid to banks: Application of the market economy investor principle. In Research handbook on state aid in the banking sector, ed. F.-C. Laprévote, J. Gray, and F. de Cecco, 87-106. Cheltenham: Edward Elgar.

35. Nicolaides, P. 2019. Ten years of state aid to financial institutions: is there still a "serious disturbance"? European State Aid Law Quarterly 18 (2): 121-137.

36. Nicolaides, P. 2020. Covid-19 can affect banks too: Application of EU banking and state aid rules. European State Aid Law Quarterly 19 (1): 29-38.

37. Nicolaides, P., and O'Connor, T. 2018. Is the Bank-Sovereign Link Truly Severed. Bruges European Economics Paper 43: College of Europe.

38. NMI Technologietransfer GmbH v EuroNorm GmbH. 2020. ECLI:EU:T:2020:754.

39. Portigon v Single Resolution Board. 2019. ECLI:EU:T:2019:824.

40. Single Resolution Board. 2019. Public Interest Assessment: SRB Approach. Paper presented by the Single Resolution Board; 28 June 2019, Brussels, Belgium.

41. Single Resolution Board. 2017. Decision of the Single Resolution Board concerning the assessment of the conditions for resolution in respect of Veneto Banca S.p.A. (the "Institution"), with the Legal Entity Identifier 459300W9STRUCJ2DLU64, addressed to Banca d'Italia in its capacity as National Resolution Authority. SRB/EES/2017/11, 23 June 2017. 
42. Single Resolution Board. 2017. Decision of the Single Resolution Board concerning the assessment of the conditions for resolution in respect of Banca Popolare di Vicenza S.p.A. (the "Institution"), with the Legal Entity Identifier V3AFM0G2D3A6E0QWDG59, addressed to Banca d'Italia in its capacity as National Resolution Authority. SRB/EES/2017/12, 23 June 2017.

43. Single Resolution Board. 2018. Decision of the Single Resolution Board concerning the assessment of the conditions for resolution in respect of ABLV Bank, AS. SRB/EES/2018/09, 23 February 2018.

44. Single Resolution Board. 2020. Decision of the Single Resolution Board determining whether compensation needs to be granted to the shareholders and creditors in respect of which the resolution actions concerning Banco Popular Español S.A. have been effected. SRB/EES/2020/52, 17 March 2020.
Publisher's Note Springer Nature remains neutral with regard to jurisdictional claims in published maps and institutional affiliations.

Phedon Nicolaides is professor at the University of Maastricht and visiting professor at the College of Europe, Bruges, and LUISS University, Rome. In 2012-2018, he held the "Jan Tinbergen" chair in European economics at the College of Europe. He is currently advisor to the Legal Service of the Republic of Cyprus and the Maltese Development Bank on issues of state aid. 